\title{
Korupsi Mengancam Desa Celukan Bawang
}

\author{
Ayu Verayanti ${ }^{1 *}$, I Made Gata S.W ${ }^{1}$, Nyoman Julita Sari ${ }^{1}$, Mahendra Alfarizy ${ }^{1}$, Maria \\ Apolonia Koda ${ }^{1}$
}

${ }^{1}$ Universitas Pendidikan Ganesha, Bali

\section{A R T I C L E I N F O}

Article history:

Received 12 Desember 2019

Accepted 23 Desember 2019

Available online 31

Desember 2019

\section{Kata Kunci:}

Bahaya Korupsi;

Kerentanan Korupsi;

Dampak Korupsi

Keywords:

Corruption Hazard;

Impact of Corruption
Corruption Vulnerability;

\begin{abstract}
A B S T R A K
Penelitian ini dilaksanakan untuk mengetahui (1) bahaya dari kasus korupsi, (2) kerentanan dari kasus korupsi dan, (3) dampak dari kasus korupsi yang terjadi di Desa Celukan Bawang. Metode yang digunakan dalam penelitian ini adalah metode kualitatif, dengan analisis data primer dan data sekunder. Hasil penelitian ini menunjukan bahwa : (1) kasus korupsi di Desa Celukan Bawang memberikan bahaya bagi warga seperti pembangunan yang direncakan guna meningkatkan fasilitas desa tidak berjalan, bahaya bagi standar moral masyarakat dan rusaknya generasi muda, (2) kasus korupsi ini rentan kepada orang yang memiliki jabatan, berpendapatan rendah dan penyelahgunaan kekuasaan dan (3) dampak yang ditimbulkan yaitu dampak primer dan dampak sekunder. Dampak primer: kerugian Negara, dinonaktifkan dari jabatan, dan pelanggaran pasal Undang-Undang. Dampak sekunder: mendapat gunjingan dan dikucilkan, serta nama baik keluarga tercemar.
\end{abstract}

\section{A B S T R A C T}

This research was conducted to determine (1) the dangers of corruption cases, (2) the vulnerability of corruption cases and, (3) the impact of corruption cases that occurred in Celukan Bawang Village. The method used in this study is a qualitative method with an analysis of primary and secondary data. The results of this study indicate that: (1) corruption cases in Celukan Bawang Village pose dangers to residents such as development planned to improve village facilities that do not work, risk to the moral standards of the community and damage to the younger generation, (2) these corruption cases are vulnerable to people who have a position, low income and abuse of power and (3) the impact caused is the primary impact and secondary impact. Significant impact: State loss, deactivation from the position, and violation of Article of the Act. Secondary effect: gossiped and isolated, and the family's reputation is tarnished.

Copyright @ Universitas Pendidikan Ganesha. All rights reserved. 


\section{Pendahuluan}

Bencana merupakan salah satu kejadian yang mengancam kehidupan manusia. Bencana didefinisikan sebagai hasil dari proses yang tidak sinergi antara ancaman (threatness), baik dari dalam (internal) maupun dari luar (eksternal) dengan kemampuan dan kewaspadaan yang dimiliki individu maupun masyarakat (Wesnawa \& Christiawan, 2014). Indonesia merupakan salah satu negara yang rentan terhadap adanya bencana.Bencana yang terjadi di Indonesia sendiri meliputi berbagai macam jenis. Berdasarkan UU No. 24 Tahun 2007, bencana dibedakan menjadi 3 bentuk yaitu bencana alam, bencana non alam, dan bencana sosial.

Menurut Indeks Rawan Bencana Indonesia bahaya adalah suatu kejadian atau peristiwa yang mempunyai potensi dapat menimbulkan kerusakan, kehilangan jiwa manusia, atau kerusakan lingkungan. Kerentanan adalah suatu kondisi yang ditentukan oleh faktor-faktor atau proses-proses fisik, sosial, ekonomi, dan lingkungan yang mengakibatkan kerawanan masyarakat dalam menghadapi bahaya (Wesnawa dan Christiawan, 2014). Ketiga jenis bencana tersebut hampir setiap hari setiap saat dapat terjadi di Indonesia seperti bencana alam yang ada di Indonesia seperti gunung erupsi, gempa bumi, dan tsunami yang bersumber dari dua jalur pegunungan yang aktif serta tiga lempeng yang aktif. Bencana non alam pun juga tidak terlepas terjadi di Indonesia seperti wabah penyakit seperti DBD yang sering terjadi pada musim penghujan dan kecelakaan teknologi seperti kecelakaan kendaraan yang hampir setiap saat terjadi di Indonesia.Bencana sosial juga dapat terjadi di Indonesia dimana bencana sosial merupakan bencana yang disebabkan atau diakibatkan oleh peristiwa atau serangkaian peristiwa yang diakibatkan oleh manusia yang meliputi konflik sosial, teror, dan yang paling sering terjadi yaitu kasus korupsi.

Istilah korupsi berasal dari bahasa latin yakni corruptio. Dalam bahasa Inggris adalah corruption atau corrupt, dalam bahasa Perancis disebut corruption dan dalam bahasa Belanda disebut dengan coruptie. Agaknya dari bahasa Belanda itulah lahir kata korupsi dalam bahasa Indonesia. Korup berarti busuk, buruk; suka menerima uang sogok (memakai kekuasaannya untuk kepentingan sendiri dan sebagainya). Korupsi adalah perbuatan yang buruk (seperti penggelapan uang, penerimaan uang sogok dan sebagainya). Korupsi berakibat sangat berbahaya bagi kehidupan manusia, baik aspek kehidupan sosial, politik, birokrasi, ekonomi,4 dan individu. Bahaya korupsi bagi kehidupan diibaratkan bahwa korupsi adalah seperti kanker dalam darah, sehingga si empunya badan harus selalu melakukan "cuci darah" terus menerus jika ia menginginkan dapat hidup terus.

Korupsi masih menjadi permasalahan yang terjadi di Indonesia. Berdasarkan Indeks Persepsi Korupsi(IPK) tahun 2018 Indonesia menempati posisi ke-89 dari 180 negara. Nilai yang didapatkan olehIndonesia yakni 38 dengan skala 0-100, semakin rendah nilainya maka semakin korup negaranya,begitu pun sebaliknya. Apabila dibandingkan dengan tahun 2017, Indonesia menempati urutan ke-96dengan nilai 37. Peningkatan 1 (satu) poin dalam IPK tidak menjadikan penegakan hukum dalampemberantasan korupsi maksimal meskipun dari segi posisi meningkat. Kondisi ini perlu menjadibahan evaluasi bagi aparat penegak hukum dalam menyusun strategi pemberantasan korupsi.

Indonesia dengan kasus korupsi yang ada dapat dikatakan tidak bisa terlepaskan dimana negara Indonesia adalah negara hukum. Negara hukum merupakan cita-cita sekaligus prinsip dalam penyelenggaraan praktik bernegara (Mulyanto, 2016). Sebagai negara hukum jelas segala sesuatu yang dilakukan oleh masyarakat diatur dalam peraturan perundang undangan termasuk kasus-kasus pelanggaran hukum yang ada seperti korupsi. Korupsi yang ada di Indonesia hampir setiap hari menjadi pembicaraan di media massa. Korupsi bisa diartikan sebagai kasus penggelapan baik itu uang ataupun barang. Korupsi terjadi karena adanya kelemahan corporate govermance baik pada korporasi maupun pemerintahan (Lidyah, 2016). Korupsi yang ada di Indonesia sudah hampir menjadi bagian dari kehidupan masyarakat dan menyusup dalam sistem penyelenggaraan pemerintahan (Rumesten, 2014). Menurut Wattimena (dalam Dewi, 2018) mengatakan bahwa korupsi bukan hanya persoalan hukum namun juga persoalan kultur. Salah satu efek negatif yang paling berbahaya dari korupsi pada jangka panjang yakni rusaknya generasi muda yang dimana dalam masyarakat, generasi muda akan menganggap bahwa korupsi sebagai hal biasa. 
Di Indonesia, sejak berlakunya UU No. 22 tahun 1999, praktik korupsi di Indonesia yang sebelumnya lebih banyak terjadi ranah birokrasi dan perbankan, kini sudah merambah masuk ke lembaga legislatif (Said, 2011). Kasus yang terjadi dalam lembaga legislatif tidak hanya di pemerintahan pusat saja melainkan pemerintahan daerah dan bahkan di tingkat desa juga tidak terlepas dari kasus korupsi yang berkaitan dengan upaya pembangunan.Dapat dikatakan bahwa korupsi itu sendiri tidak memandang siapa, jabatan, dan pelakuknya karena korupsi sendiri dapat dilakukan secara bersama-sama.

Selain itu juga kasus korupsi yang ada tidak mengenal lokasi dalam artian tidak hanya di dalam suatu tingkatan yang tinggi seperti pemerintah pusat melainkan juga dapat ditemukan di tingkat yang rendah di pemerintahan desa.Terdapat beberapa kasus korupsi di tingkat desa yang terjadi dan melibatkan beberapa oknum seperti perangkat desa, kerjasama desa dengan instansi dan masyarakat itu sendiri dalam desa tersebut. Penelitian ini bertujuan untuk mengetahui bahaya kasus korupsi, kerentanan dan dampak yang ditimbulkan kasus korupsi tersebut. Salah satu kasus korupsi yang ada di tingkat desa yaitu kasus korupsi di Celukan Bawang oleh Perbekel Desa Celukan Bawang. Maka dari itu dilakukanlah penelitian yang berjudul Kasus Korupsi Di Desa Celukan Bawang.

\section{Metode}

Metode yang digunakan dalam penelitian dalam penelitian Mitigasi adalah penelitian kualitatif. Kualitatif riset didefinisikan sebagai suatu proses yang mencoba untuk mendapatkan pemahaman yang lebih baik mengenai kompleksitas yang ada dalam interaksi manusia. Definisi diatas menunjukan beberapa kata kunci dalam riset kualitatif, yaitu : proses, pemahaman, kompleksitas, interaksi dan manusia. Proses dalam melakukan penelitian merupakan penekanan dalam riset kualitatif oleh karena itu dalam melaksanakan penelitian, penelitian lebih fokus pada proses dari pada hasil akhir.

Penelitian kualitatif merupakan penelitian yang bersifat naturalistik karena sesuai dengan situasi yang ada di lapangan, penelitian bersifat natural atau wajar, sebagaimana adanya, tanpa dimanipulasi, diatur dengan eksperimen atau test. Penelitian kualitatif tidak ada kebenaran yang mutlak, kebenaran itu sangat kompleks dan tak ada suatu teori yang dapat menangkapnya.

Data dalam penelitian kualitatif bersifat deskriptif bukan angka. Data dapat berupa gejala-gejala, kejadian dan peristiwa yang kemudian dianalisis dalam bentuk kategori-kategori. Jika dilihat dari jenis, maka kita dapat membedakan data kualitatif sebagai data primer dan data sekunder. Data primer data ini berupa teks hasil wawancara dan diperoleh melalui wawancara dengan informan yang sedang dijadikan sampel dalam penelitiannya. Data dapat direkam atau dicatat oleh peneliti. Data tersebut diperoleh dari satu informan, terkait kebenaran kasus korupsi yang dikajian dan dampaknya. Data sekunder berupa data-data yang sudah tersedia dan dapat diperoleh oleh peneliti dengan cara membaca, melihat atau mendengarkan Jenis data yang digunakan dalam penelitian ini adalah data sekunder. teknik pengambilan data yang digunakan yaitu dengan mengambil dari berbagai sumber media. Data yang diperoleh yaitu faktor pemicu terjadinya korupsi, pelaku yang rentan terlibat dalam kasus korupsi, dampak yang ditimbulkan dari kasus korupsi serta jurnal-jurnal yang mengkaji kasus korupsi sebagai perbandingan.

Penelitian ini dilakukan dengan dua tahapan yaitu persiapan dan proses. Tahapan persiapan adalah tahapan meyiapkan hal-hal yang dibutuhkan dalam penelitian. Hal yang disiapkan adalah menentukan fokus kajian, pembuatan instrumen, dan pengumpulan data. Tahapan proses merupakan tahapan mengumpulan data dengan data yang didapat dalam berbagai sumber. 


\section{Hasil dan Pembahasan}

\subsection{1 Bahaya Kasus Korupsi di Desa Celukan Bawang}

Menurut Edward Aspinal (dalam Airliman, 2016) bahwa politik uang hanya ada di Indonesia. Jika korupsi dalam suatu masyarakat telah merajalela dan menjadi makanan setiap masyarakat setiap hari, maka akibatnya akan menjadikan masyarat yang kacau, tidak ada sistem sosial yang dapat berlaku dengan baik. Sehingga individu hanya akan mementingkan diri sendiri (self interst) bahkan menjadi selfishness (Setiadi, 2018). Kasus korupsi merupakan suatu kejahatan yang hampir ditemukan dalam setiap pemerintahan, hal ini terbukti yang terjadi di Desa Celukan Bawang tersebut.

Penyebab adanya tindakan korupsi sangat bervariasi dan beranekaragam (Wesnawa \& Christiawan, 2014). Adapun faktor-faktor yang menyebabkan tindakan korupsi adalah sebagai berikut: Ketiadaan atau kelemahan kepemimpinan dalam menjinakan korupsi, Kelemahankelemahan pengajaran agama dan etika. Kurangnya pendidikan dan adanya banyak kemiskinan. Tidak adanya tindakan hukum yang tegas. Kelangkaan lingkungan yang subur, untuk prilaku anti korupsi. Struktur pemerintahan dan keadaan masyarakat semakin majemuk. Perubahan radikal, merupakan suatu sistem nilai yang mengalami perubahan radikal, korupsi muncul sebagai penyakit transisional.

Disisi lain, fakor-faktor yang dapat menyebkan tindakan korupsi secara teoritis adalah sebagai berikut: greeds (keserakahan) berkaitan dengan adanya prilaku serakah secara potensial ada dalam diri setiap orang. Opportunities (kesempatan) berkaitan dengan keadaan organisasi atau instansi atau masyarakat yang sedemikian rupa sehingga terbuka kesempatan seseorang melakukan kecurangan. Needs (kebutuhan) berkaitan dengan faktor-faktor yang dibutuhkan oleh indivisu-individu untuk menunjang hidupnya yang wajar. Exposures (pengungkapan) berkaitan dengan tindakan atau konsekuensi yang dihadapi oleh pelaku kecurangan apabila pelaku diketemukan melakukan kecurangan.

Faktor-faktor tersebut, dalam kasus korupsi di Celukan Bawang yang menyebabkan tindakan kasus korupsi yaitu greeds (keserakahan) dan opportunities (kesempatan). Keserakahan terlihat dari jabatan yang dimiliki perbekel Desa Celukan Bawang, dari jabatan tersebut tentu sudah mendapatkan gaji. Namun dengan besarnya dana untuk pembangunan desa, menyebabkan perbekel tersebut menginginkan material lebih (serakah). Selain itu, adanya opportunities (kesempatan), dengan jabatan perbekel tersebut menyebabkan adanya kekuasaan, sehingga kesempatan untuk melakukan tindakan korupsi lebih besar.

Sehingga jika dilihat pada kasus korupsi perbekel di Desa Celukan Bawang, memberikan bahaya bagi warga tersebut karena pembangunan yang direncakan guna meningkatkan fasilitas desa tidak berjalan. Selain itu, menurut (Setiadi, 2018) bahwa bahaya korupsi meliputi Korupsi juga membahayakan terhadap standar moral dan intelektual masyarakat, korupsi merusak perkembangan ekonomi suatu bangsa, efek negatif yang paling berbahaya dari korupsi pada jangka panjang adalah rusaknya generasi muda karena menganggap korupsi sebagai hal biasa, dan masyarakat tidak akan percaya kepada pemerintah akibatnya mereka tidak akan patuh dan tunduk pada otoritas mereka. Jika korupsi dalam suatu masyarakat telah merajalela dan menjadi makanan masyarakat setiap hari, maka akibatnya akan menjadikan masyarakat tersebut sebagai masyarakat yang kacau, tidak ada sistem sosial yang dapat berlaku dengan baik. Setiap individu dalam masyarakat hanya akan mementingkan diri sendiri (self interest), bahkan selfishness. Tidak akan ada kerja sama dan persaudaraan yang tulus.

Fakta empirik dari hasil penelitian di banyak negara dan dukungan teoritik oleh para saintis sosial menunjukkan bahwa korupsi berpengaruh negatif terhadap rasa keadilan sosial dan kesetaraan sosial. Korupsi menyebabkan perbedaan yang tajam di antara kelompok sosial dan individu baik dalam hal pendapatan, prestis, kekuasaan dan lain-lain. Korupsi juga membahayakan terhadap standar moral dan intelektual masyarakat. Ketika korupsi merajalela, maka tidak ada nilai utama atau kemulyaan dalam masyarakat. Theobald menyatakan bahwa korupsi menimbulkan iklim ketamakan, selfishness, dan sinisism. Banyak pakar menyatakan bahwa korupsi menyebabkan sikap individu menempatkan kepentingan diri sendiri di atas segala sesuatu yang lain dan hanya akan berpikir tentang dirinya sendiri semata-mata. 
Bahaya koupsi dapat menyasar pada generasi muda, politik, ekonomi dan birokrasi (Setiadi, 2018) sebagai berikut.

(1) Bahaya korupsi terhadap generasi muda

Salah satu efek negatif yang paling berbahaya dari korupsi pada jangka panjang adalah rusaknya generasi muda. Dalam masyarakat yang korupsi telah menjadi makanan seharihari, anak tumbuh dengan pribadi antisosial, selanjutnya generasi muda akan menganggap bahwa korupsi sebagai hal biasa (atau bahkan budaya), sehingga perkembangan pribadinya menjadi terbiasa dengan sifat tidak jujur dan tidak bertanggung jawab. Jika generasi muda suatu bangsa keadaannya seperti itu, bisa dibayangkan betapa suramnya masa depan bangsa tersebut.

(2) Bahaya Korupsi terhadap politik

Kekuasaan politik yang dicapai dengan korupsi akan menghasilkan pemerintahan dan pemimpin masyarakat yang tidak legitimate di mata publik. Jika demikian keadaannya, maka masyarakat tidak akan percaya terhadap pemerintah dan pemimpin tersebut, akibatnya mereka tidak akan patuh dan tunduk pada otoritas mereka. Praktik korupsi yang meluas dalam politik seperti pemilu yang curang, kekerasan dalam pemilu, money politics dan lain-lain juga dapat menyebabkan rusaknya demokrasi, karena untuk mempertahankan kekuasaan, penguasa korup itu akan menggunakan kekerasan (otoriter) atau menyebarkan korupsi lebih luas lagi di masyarakat. Di samping itu, keadaan yang demikian itu akan memicu terjadinya instabilitas sosial politik dan integrasi sosial, karena terjadi pertentangan antara penguasa dan rakyat. Bahkan dalam banyak kasus, hal ini menyebabkan jatuhnya kekuasaan pemerintahan secara tidak terhormat, seperti yang terjadi di Indonesia.

(3) Bahaya korupsi bagi ekonomi

Korupsi merusak perkembangan ekonomi suatu bangsa. Jika suatu projek ekonomi dijalankan sarat dengan unsur-unsur korupsi (penyuapan untuk kelulusan projek, nepotisme) dalam penunjukan pelaksana projek, penggelepan dalam pelaksanaannya dan lain-lain bentuk korupsi dalam projek), maka pertumbuhan ekonomi yang diharapkan dari projek tersebut tidak akan tercapai. Penelitian empirik oleh Transparency International menunjukkan bahwa korupsi juga mengakibatkan berkurangnya investasi dari modal dalam negeri maupun luar negeri, karena para investor akan berpikir dua kali untuk membayar biaya yang lebih tinggi dari semestinya dalam berinvestasi (seperti untuk penyuapan pejabat agar dapat izin, biaya keamanan kepada pihak keamanan agar investasinya aman dan lain-lain biaya yang tidak perlu). Sejak tahun 1997, investor dari negara-negera maju (Amerika, Inggris dan lain-lain) cenderung lebih suka menginvestasikan dananya dalam bentuk Foreign Direct Investment (FDI) kepada negara yang tingkat korupsinya kecil.

(4) Bahaya korupsi bagi birokrasi

Korupsi juga menyebabkan tidak efisiennya birokrasi dan meningkatnya biaya administrasi dalam birokrasi. Jika birokrasi telah dikungkungi oleh korupsi dengan berbagai bentuknya, maka prinsip dasar birokrasi yang rasional, efisien, dan berkualitas akan tidak pernah terlaksana. Kualitas layanan pasti sangat jelek dan mengecewakan publik. Hanya orang yang berpunya saja yang akan dapat layanan baik karena mampu menyuap. Keadaan ini dapat menyebabkan meluasnya keresahan sosial, ketidaksetaraan sosial dan selanjutnya mungkin kemarahan sosial yang menyebabkan jatuhnya para birokrat

\subsection{Kerentanan Kasus Korupsi di Desa Celukan Bawang}

Modus korupsi dikalangan Dewan terhadap dana Anggaran Pendapatan dan Belanja Daerah (APBD) yang marak terjadi di berbagai daerah di Indonesia, merupakan modus korupsi yang dilegalisasi (Switri, 2007). Pihak-pihak yang rentan dalam melakukan tindakan korupsi dalah orang-orang yang memiliki keterbatasan finansial namun memiliki keinginan yang tak terbatas dalam hidup. Keinginan yang tak terbatas ini khususnya dalam hal gaya hidup akhirnya mendorong orang untuk melakukan tindakan korupsi agar keinginannya dapat terpenuhi. Kelompok orang yang memiliki kemungkinan besar dalam melakukan tindakan korupsi ini memiliki beberapa indikasi seperti : memiliki pendidikan yang tinggi serta jabatan, 
berpendapatan rendah atau tidak mencukupi dan penyalahgunaan kekuasaan dan kesempatan untuk memperkaya diri.

Selain itu, adanya keserakahan yang ada pada pemegang kekuasaan memunculkan sifat korupsi itu sendiri dan lemahnya penegakan hukum. Kasus korupsi yang terjadi di CelukanBawang yang melibatkan kepala desa Celukan Bawang ini termasuk dalam indiksai yang ketiga yaitu penyalahgunaan kekuasaan dan kesempatan untuk memperkaya diri, karena dalam kasus ini dana yang seharusnya masuk kedalam rekening desa malah masuk kerekening pribadi dari kepala desa Celukan Bawang sendiri. Hal ini dapat terjadi tentunya dengan unsur kesengajaan karena dalam memberikan data atau nomer rekening yang menyangkut desa tentunya harus lebih teliti sehingga kesalahan seperti salah nomer rekening tidak mungkin terjadi.

Pihak kepala desa sendiri tentunya memiliki latarbelakang pendidikan yang bagus sehingga dapat menjadi kepala desa, namun pendidikan yang dimiliki ini tidak digunakan dengan baik namun malah digunakan untuk melakukan tindakan korupsi yang tentu saja sangat merugikan desa Celukan Bawang hanya untuk memperkaya dirinya sendiri demi memenuhi gaya hidup yang sekarang. Tantangan bagi Korupsi adalah canggihnya modus operandi yang terbilang sistematis lagi terorganisir (Mulyanto, 2016).

Alamsyah, Abid, \& Sunaryanto (2018) dalam laporan Indonesia Corruption Watch (ICW) telah melakukan pemetaan kasus dugaan korupsi yang memperlihatkan kerentanan korupsi hampir di segala sektor dan berbagai modus. da sebanyak 13 modus yang ICW klaster kerap digunakan oleh tersangka korupsi. Modusnya antara lain:mark up,penyalahgunaan anggaran, penggelapan, laporan fiktif, suap, kegiatan/proyek fiktif, pungutan liar,penyalahgunaan wewenang, penyunatan/pemotongan, gratifikasi, pemerasan, anggaran ganda danmark down.Pemetaan modus dapat digunakan sebagai upaya untuk melakukan pencegahan dalam konteks 6perbaikan sistem. Berikut hasil pemantauan yang dilakukan oleh ICW sepanjang tahun 2018 seperti terlihat pada Tabel 1.

Tabel 1. Pemetaan Korupsi Berdasarkan Modus

\begin{tabular}{|c|l|c|c|c|c|}
\hline No & \multicolumn{1}{|c|}{ Modus } & $\begin{array}{c}\text { Jumlah } \\
\text { Kasus }\end{array}$ & $\begin{array}{c}\text { Nilai Kerugian } \\
\text { Negara }\end{array}$ & $\begin{array}{c}\text { Nilai } \\
\text { Suap/Gratifikasi/Nilai } \\
\text { Pungutan Liar }\end{array}$ & $\begin{array}{c}\text { Nilai } \\
\text { Pencucian } \\
\text { Uang }\end{array}$ \\
\hline 1 & Mark Up & 76 & Rp541 miliar & - & - \\
\hline 2 & $\begin{array}{l}\text { Penyalahgunaan } \\
\text { Anggaran }\end{array}$ & 68 & Rp455 miliar & - & - \\
\hline 3 & Penggelapan & 62 & Rp441 miliar & - & - \\
\hline 4 & Laporan Fiktif & 59 & Rp160 miliar & - & \\
\hline 5 & Suap & 51 & - & Rp67,9 miliar & Rp57 miliar \\
\hline 6 & Kegiatan/Proyek Fiktif & 47 & Rp321 miliar & - & - \\
\hline 7 & Pungutan Liar & 43 & - & Rp6,7 miliar & - \\
\hline 8 & $\begin{array}{l}\text { Penyalahgunaan } \\
\text { Wewenang }\end{array}$ & 20 & Rp3,6 triliun & - & - \\
\hline 9 & Penyunatan/Pemotongan & 16 & Rp38,2 miliar & - & - \\
\hline 10 & Gratifikasi & 7 & - & Rp65,9 miliar & Rp34 miliar \\
\hline 11 & Pemerasan & 2 & - & Rp 80 juta & - \\
\hline 12 & Anggaran Ganda & 2 & Rp2,7 miliar & - & - \\
\hline 13 & Mark Down & 1 & Rp1,4 miliar & - & - \\
\hline \multicolumn{2}{|c|}{ TOTAL } & 454 & Rp5,6 triliun & Rp140,8 miliar & Rp91 miliar \\
\hline
\end{tabular}

Modus yang paling banyak dilakukan oleh tersangka korupsi yaknimark up. Ada sebanyak 76 kasuskorupsi yang melibatkan 185 orang tersangka. Artinya per kasus melibatkan 2 (dua) orang terasngkakorupsi. Nilai kerugian negara yang ditimbulkan akibat melakukan penggelembungan harga sebesarRp541 miliar. Rata-rata nilai kerugian negara yang timbul akibat kasus dugaan korupsi bermodusmarkupsebesar Rp2,9 miliar per kasus. 
ICW juga melakukan pemetaan kasus dugaan korupsi berdasarkan sektor yang rawan dikorupsi. Adasebanyak 31 sektor yang ICW klaster rawan terjadi korupsi. Sektornya beragam, mulai dari yangberkaitan dengan sumber daya alam, pelayanan publik, tata kelola pemerintahan, hingga sosial kemasyarakatan. Pemetaan sektor yang rawan dikorupsi dapat digunakan sebagai upaya untuk merancang aksipencegahan. Berikut hasil pemantauan yang dilakukan oleh ICW sepanjang tahun 2018 seperti terlihat pada Tabel 2.

Tabel 2. Pemetaan Korupsi Berdasarkan Sektor

\begin{tabular}{|c|c|c|c|c|c|c|}
\hline No & Sektor & $\begin{array}{l}\text { Jumlah } \\
\text { Kasus }\end{array}$ & $\begin{array}{c}\text { Nilai Kerukian } \\
\text { Mekn }\end{array}$ & Nilai Suap & $\begin{array}{c}\text { Punzutan } \\
\text { Liar } \\
\end{array}$ & $\begin{array}{c}\text { Penuucian } \\
\text { Unak: }\end{array}$ \\
\hline 1 & AnEEATan Der & 96 & Rpaz, 2 miliar & - & - & - \\
\hline 2 & Pemsintahan & 97 & Rpza7 miliar & Rp 73,5 miliar & - & Rpsy milia: \\
\hline 3 & Pendidikan & 53 & Rpd4,7 miliar & Rp2,6 miliar & Apl,4 miliar & $=$ \\
\hline 4 & Trangoortsii & 32 & Rp470 7 miliz: & Rp19.2 miliar & Fp24.8 jut & - \\
\hline 5 & Kesehatan & 21 & Rp=t, a miliar & Fp2 miliar & Rp4,9 juta & - \\
\hline b & Penkairan & 21 & Ep203. 1 miliz & - & - & - \\
\hline 7 & Pertanahan & 20 & Rp40,2 miliar & Rip32,4 jut & Rp372 jut & - \\
\hline a & $\begin{array}{l}\text { Sosilal } \\
\text { Kemasyarktatin }\end{array}$ & 19 & Rp4t, 7 milinr & - & Rp137 juth & - \\
\hline 9 & Furbankan & 16 & kp2,1 triliun & - & - & - \\
\hline 10 & Perizinan & 14 & Ep1.1 triliun & Rpd,g miliar & Rp107 jut & Rp34 miliar \\
\hline 11 & Ferdagangan & 11 & Rp1s miliar & $=$ & Ep $\$ 71$ ribu & - \\
\hline 12 & Kettenakakerjazn & 9 & Fp462,B miliar & Rp6,6 miliar & Rps miliar & $=$ \\
\hline 19 & Pertanian & 9 & Kp7,3 miliar & - & Ep1,1 miliar & - \\
\hline 14 & Fajps & 9 & Kp2,8 miliar & Rp106 juta & Rp13 juta & - \\
\hline 12 & Femilu & 8 & Rp7,9 miliar & Rptos juta & - & $=$ \\
\hline 16 & $\begin{array}{l}\text { Enerki dan } \\
\text { Listrik }\end{array}$ & 6 & Rps71 miliar & RpsLD juta & - & - \\
\hline 17 & Kependudukn & 6 & Rp3,4 miliar & - & Rpgs juta & - \\
\hline $1 B$ & Koperasi & 6 & Rep7,6 miliar & RpBo jutr & - & - \\
\hline 19 & Petermakn & 6 & Rp20,1 miliar & - & - & - \\
\hline 20 & Feradilan & 5 & $=$ & Rps,7 miliar & - & - \\
\hline 21 & Perumahan & 5 & Rplfif miliar & Rospd juta & An110 juta & - \\
\hline 22 & $\begin{array}{l}\text { Telekomumiksi } \\
\text { dan informasi }\end{array}$ & 4 & Rps,4 miliar & Rp12 miliar & Ap429 juta & - \\
\hline 23 & Fertamanan & 4 & Hp2,9 miliar & $=$ & $=$ & - \\
\hline 24 & Kenzampan & 3 & Rog, 6 miliar & HD10D Juta & - & - \\
\hline 25 & Kehutanan & 3 & Rp1,4 miliar & Rpsog juta & - & - \\
\hline 26 & olahraka & 3 & Rp342 juta & Ept miliar & - & - \\
\hline 27 & Pariwista & 3 & Rp461 juta & - & - & - \\
\hline $2 B$ & Kebersihan & 2 & Rel,s miliar & - & - & - \\
\hline 29 & $\begin{array}{l}\text { Pemadam } \\
\text { Kebakaran }\end{array}$ & 2 & Rp390 juta & RpS juth & - & - \\
\hline 30 & Kepolisian & 1 & $=$ & - & Rp<0 juta & - \\
\hline 31 & Marufaktur & 1 & Rp6sojuta & - & - & - \\
\hline & TOTAL & & & & & \\
\hline
\end{tabular}




\subsection{Dampak kasus korupsi di Desa Celukan Bawang}

Korupsi berdampak sangat buruk bagi kehidupan berbangsa dan bernegara karena telah terjadi kebusukan, ketidakjujuran, dan melukai rasa keadilan masyarakat. Penyimpangan anggaran yang terjadi akibat korupsi telah menurunkan kualitas pelayanan negara kepada masyarakat. Pada tingkat makro, penyimpangan dana masyarakat ke dalam kantong pribadi telah menurunkan kemampuan negara untuk memberikan hal-hal yang bermanfaat untuk masyarakat, seperti: pendidikan, perlindungan lingkungan, penelitian, dan pembangunan. Pada tingkat mikro, korupsi telah meningkatkan ketidakpastian adanya pelayanan yang baik dari pemerintah kepada masyarakat.

Korupsi di Celukan Bawang pastinya akan menyebabkan dampak-dampak negative, baik itu berupa dampak primer dan dampak sekunder. Menurut Fauzan (2012) tindakan korupsi diyakini merupakan ancaman serius yang akibatnya tidak saja menyerang sendi-sendi perekonomian nasional suatu negara, tetapi juga dapat memengaruhi sistem perekonomian internasional serta melemahkan nilai-nilai keadilan disemua negara. Kasus korupsi ini sudah merajalela hingga ke Desa, seperti pada kasus korupsi perbekel di Desa Celukan Bawang. Sehingga kasus ini berdampak negatif primer dan sekunder seperti terlihat pada Tabel 3.

Table 3. Data kependudukan Desa Ambengan April-Desember 2018.

\begin{tabular}{|l|l|l|}
\hline No & \multicolumn{1}{|c|}{ Struktur Dampak } & \multicolumn{1}{c|}{ Deskripsi } \\
\hline 1 & Dampak Primer & Kerugian negara \\
\cline { 3 - 3 } & & Dinonaktifkan dari jabatan \\
\cline { 3 - 3 } & & Pelanggaran pasal perundang-undangan \\
\hline 2 & Dampak Sekunder & $\begin{array}{l}\text { Keluarga yang bersangkutan mendapat gunjingan } \\
\text { dan dikucilkan }\end{array}$ \\
\cline { 3 - 3 } & & Nama baik keluarga tercemar \\
\hline
\end{tabular}

Pada Tabel 3 terlihat bahwa dampak primer yang ditimbulkan dari pelaku kosrupsi secara langsung, yaitu kerugian negara, dana yang dikorupsi tersebut berdampak langsung pada kerugian negara mencapai 194 rupiah (Mustofa, 2019). Kemudian perbekel tersebut dinonaktifkan dari jabatan sebagai perbekel karena merugikan desa. Selain itu, dampak primer pada tabel tersebut, yaitu perbekel tersebut melanggar pasal 2 jo 18 Undang-undang Tipikor serta pasal 55 jo pasal 64 KUHP dan subsider pasal 3, ancaman hukuman minimal 4 tahun dan maksimal 20 tahun. Hal ini menyebkan perbekel tersebut dijerat dalam penjara. Pada tabel diatas, terdapat dampak sekunder kasus korupsi tersebut bahwa keluarga yang bersangkutan mendapat gunjingan dan dikucilkan dari masyarakat dan keluarga menjadi malu. Selain itu, menurut satu informan bahwa keluarga bersangkutan juga dipandang masyarakat setempat sudah kehilangan kepercayaan dari masyarakat untuk mendapat struktuk kepengurusan di Desa. Hal ini juga terdapat dalam kasus korupsi di tempat lain yang dilakukan oleh kepala sekolah, yang menyebabkan siswa malu dan mogok sekolah.

Korupsi berkontribusi dalam mengurangi pertumbuhan ekonomi dengan menurunkan kualitas infrastruktur dan pelayanan publik, mengurangi pajak, membuat pemerintah justru bergandengan dengan para pencari rente daripada melakukan aktivitas yang produktif, dan akhirnya mendistorsi komposisi pengeluaran pemerintah. Korupsi berimplikasi negatif terhadap pertumbuhan ekonomi karena korupsi berpengaruh langsung terhadap tingkat investasi, rendahnya tingkat investasi swasta karena besarnya biaya suap dalam perizinan usaha, dan terdistorsinya investasi pemerintah oleh kelompok kepentingan.

Dampak korupsi baik langsung maupun tidak langsung akan memengaruhi indikatorindikator makro ekonomi suatu negara. Korupsi dapat menciptakan kesenjangan yang lebar antara pertumbuhan ekonomi yang telah dicapai dengan potensi pertumbuhan ekonomi yang sebenarnya bisa dicapai, sehingga memengaruhi proses pertumbuhan ekonomi nasional. Analisanya adalah korupsi menimbulkan inefisiensi dan pemborosan dari sumber ekonomi periode sebelumnya, karena hasil dari pengelolaan sumberdaya ekonomi yang ada tidak semuanya dikembalikan sebagai modal perputaran ekonomi secara multiplier, keuntungan yang 
diperoleh dari korupsi kemungkinan besar digunakan bermewah-mewah atau dilarikan ke rekening pribadi di luar negeri bukan di alihkan ke sektor investasi

Secara sederhana korupsi pada dasarnya adalah sebuah misalokasi sumberdaya, yang artinya, korupsi memindahkan sumberdaya dari kegiatan produktif atau memiliki manfaat sosial tinggi ke kegiatan tidak produktif dan menciptakan biaya sosial. Biaya ekonomi korupsi dapat dikaitkan sebagai sumber daya yang terbuang, yang dapat digambarkan pada kurva batas kemungkinan produksi (Production Posibility Frontier/ PPF).

Akan tetapi selama ini terdapat dua sisi pandangan yang berbeda mengenai efek korupsi, beberapa diantaranya memperlihatkan efek buruk, dan sisi lainnya memperlihatkan efek baik korupsi terhadap pertumbuhan ekonomi. Banyak pakar menyatakan bahwa korupsi membuat aktivitas ekonomi berjalan lancar dan akhirnya pertumbuhan ekonomi akan meningkat. Menurut argumen ini, aktivitas bisnis diibaratkan sebagai roda perekonomian dan korupsi dapat menjadi "minyak pelumas" bagi roda itu, terdapat beberapa alasan dari argumen ini. Pertama, korupsi dapat menjadi uang pelicin atau speed money sehingga dapat menghindari terjadinya penundaan birokrasi. Hal ini di dukung oleh teori keseimbangan Nash pada noncooperative game adanya suap dapat meminimalisasi biaya tunggu atau waiting cost sehingga dapat mengurangi biaya-biaya, yang pada akhirnya menurunkan inefisiensi dari pemerintah. Namun ada beberapa ahli yang membantah pandangan tersebut, menurut mereka teori speed money tidak terjadi. Pada kenyataannya para birokrat dapat memperlambat kerja mereka untuk mendapatkan lebih banyak suap.

Alasan yang kedua adalah para pegawai struktural yang mendapat pembayaran rendah, ditambah kurangnya tanggung jawab mereka, tidak termotivasi untuk bekerja lebih efisien. Namun dengan adanya suap akan mendorong mereka untuk bekerja lebih efisien. Alasan yang ketiga dari sisi kesejahteraan (welfare), banyak layanan atau barang publik masih dimonopoli oleh pemerintah, tapi apabila ada aparat pemerintah yang menjualnya di pasar gelap (secara illegal), maka konsumen bisa mendapatkan barang atau pelayanan publik tersebut dibawah harga resmi. Oknum aparat akan menerima seluruh pembayaran untuk dirinya sendiri, sehingga negara kehilangan pendapatan, namun konsumen mendapatkan harga di bawah harga resmi sehingga terjadi relokasi keuntungan dari negara ke konsumen (peningkatan kesejahteraan masyarakat).

Sedangkan pakar lain membuktikan bahwa korupsi menghambat pertumbuhan ekonomi negara-negara. Ia menemukan apabila Bangladesh dapat memerangi korupsi pada tingkat yang sama dengan Singapura dan jika laju pertumbuhannya mencapai 4 persen pertahun, maka laju pertumbuhan PDB tahunan per kapita rata-rata antara 1960-1985 tentu akan mencapai 1.8 persen lebih tinggi. Selain itu, Todaro \& Smith (2006) mendukung pendapat bahwa korupsi berimplikasi negatif terhadap pertumbuhan, menurutnya ketiadaan korupsi mendorong investasi dan upaya-upaya untuk memperbesar peluang perekonomian dan bukan hanya untuk memperebutkannya, dan oleh karenanya mendorong pertumbuhan ekonomi, sehingga pada umumnya perbaikan tata kelola (governance), terutama pengurangan korupsi akan mempercepat proses pembangunan. Pemberantasan korupsi penting dilakukan, karena pemerintahan yang jujur dapat mendorong pertumbuhan dan pendapatan tinggi secara berkesinambungan.

Sedangkan menurut Swaleheen \& Stansel (2007) korupsi dapat menurunkan pertumbuhan ekonomi, ketika pelaku ekonomi memiliki pilihan yang sedikit/ kebebasan ekonomi rendah, namun pada keadaan pelaku ekonomi memiliki banyak pilihan/kebebasan ekonomi tinggi, korupsi membantu pertumbuhan dengan menyediakan jalan di sekitar kontrol pemerintah.

Korupsi selalu membawa konsekuensi negatif terhadap proses demokratisasi dan pembangunan, sebab korupsi telah mendelegetimasi dan mengurangi kepercayaan publik terhadap proses politik melalui money-politik. Korupsi juga telah mendistorsi pengambilan keputusan pada kebijakan publik, tiadanya akuntabilitas publik serta menafikan the rule of law. Di sisi lain, korupsi menyebabkan berbagai proyek pembangunan dan fasilitas umum bermutu rendah serta tidak sesuai dengan kebutuhan yang semestinya, sehingga menghambat pembangunan jangka panjang yang berkelanjutan. 


\section{Simpulan dan Saran}

Dari hasil pembahasan diatas mengenai kasus korupsi di Desa Celukan Bawang, dapat disimpulkan bahaya kasus korupsi Desa Celukan Bawang adalah pembangunan yang direncanakan guna meningkatkan fasilitas desa tidak berjalan sehingga menghambat pembangunan desa. Pihak yang rentan melakukan tindak pidana korupsi yaitu memiliki pendidikan yang tinggi serta jabatan, berpendapatan rendah atau tidak mencukupi, penyalahgunaan kekuasaan dan kesempatan untuk memperkaya diri. Dampak dari kasuskorupsi di Celukan Bawang yaitu terbagi menjadi 2 yaitu dampak primer dan dampak sekunder.

Saran kepada pemerintah Indonesia umumnya dan pemerintah Kabupaten Buleleng khususnya untuk terus meningkatkan posisi-posisi dalam memberantas korupsi yang mewabah di kalangan pemimpin masyarakat baik lungkup kecil maupun besar. Serta meningkatkan kualitas hukum yang tegas bagi pemimpin yang melakukan tindakan korupsi.Agar kasus korupsi yang dilakukan perbekel di Desa Celukan Bawang tersebut tidak terjadi lagi atau tidak ditiru oleh generasi selanjutnya. Karna hal ini akan berpengaruh terhadap kemajuan negara. Secara signifikan, upaya strategis yang harus dilakukan berdasarkan berbagai simpulan terhadap hasil pemetaan kasus korupsi adalah: (1) perlu adanya sinergi antara penegak hukum, lembaga audit negara, dan inspektorat terkait potensi kerugian negara yang mengakibatkan terjadinya korupsi. Hal ini guna meningkatkan kinerja penegak hukum dalam penindakan kasus korupsi, (2) penegak hukum harus membuat kanal informasi bagi masyarakat sebagai ruang partisipasi untuk mengawasi kasus korupsi yang sedang berjalan di tiap instans, (3) perlu adanya pengawasan yang dilakukan oleh inspektorat daerah untuk meminimalisir terjadinya korupsi di daerah. Selain itu, perlu adanya pengawasan dari Pemerintah Pusat untuk mengawasi penyaluran dana bencana alam sehingga potensi kerugian yang dialami oleh negara dan masyarakat dapat diminimalisir, (4) penegak hukum dapat memberikan penawaran kepada tersangka korupsi untuk menjadi justice collaborator demi membongkar kejahatan hingga aktor utama, (5) penegak hukum selain harus fokus dalam aspek pidana badan, perlu juga fokus dalam aspek perampasan aset dengan menggunakan instrumen pidana pencucian uang. Supaya pengembalian aset dan memiskinkan koruptor dapat terwujud, (6) penegak hukum perlu menggali bukti lain yang mengarah pada keterlibatan korporasi dalam kejahatan korupsi. Hal ini patut untuk dilakukan agar kehidupan bangsa dapat terbebas dari praktik korupsi.

\section{Daftar Rujukan}

Airliman, S. L. (2016). Keterbukaan Keuangan Partai Politik Terhadap Praktik Pencucian Uang dari Hasil Tindak Pidana Korupsi. Jurnal Cita Hukum, 4, 225-240.

Alamsyah, W., Abid, L., \& Sunaryanto, A. (2018). Laporan Tren Penindakan Kasus Korupsi Tahun 2018.

Dewi, C. I. K. (2018). Struktur dan Agensi Analisa Sosial Terhadap Perilaku Korupsi. Dharmasmrti, 9(2), 102-123.

Fauzan, M. (2012). Implementasi Pemerintahan Yang Bersih Dalam Kerangka Rencana Aksi Daerah Pemberantasan Korupsi (RAD-PK) (Studi di Kabupaten Pemalang). Jurnal Dinamika Hukum, 12, 448-463.

Lidyah, R. (2016). Korupsi dan Akuntansi Forensik. I-Finance, 2(2), 72-91.

Mulyanto. (2016). Praktik Pembatasan Pembalikan Beban Pembuktian dalma Pengadilan Tipikor (Studi Pada Perkara Korupsi RAPBD Kota Semarang dipengadilan Tipikor Kota Semarang). Jurnal Jurisprudence, 6, 116-125.

Mustofa, A. (2019). Dijebloskan Kebui Perbekel Celukan Bawang Minta Rekanan di Proses. Retrieved from https://radarbali.jawapos.com/read/2019/08/30/153206/dijebloskanke-bui-perbekel-celukan-bawang-minta-rekanan-diproses

Rumesten, R. S. I. (2014). Korelasi Perilaku Korupsi Kepala Daerah Dengan Pilkada Langsung. Jurnal Dinamika Hukum, 14(2), 350-358.

Said, N. A. (2011). Rekonstruksi Pertanggungjawaban Pidana Terhadap Tindak Pidana Korupsi APBD yang Dilakukan Oleh Anggota DPRD. Jurnal Dinamika Hukum, 11, 135-149.

Setiadi, W. (2018). Korupsi Di Indonesia (Penyebab, Bahaya, Hambatan dan Upaya Pemberantasan Serata Regulasi). Jurnal Legislasi Indonesia, 15, 249-262. 
Swaleheen, M., \& Stansel, D. (2007). Economic Freedom, Corruption and Growth. Cato Journal, 27(3), 343-358.

Switri, S. (2007). Pemberantasan Korupsi Di Indonesia: Sebuah Upaya Reformasi Berokrasi. Jurnal Dialogue, 4, 23-42.

Todaro, M. P., \& Smith, S. C. (2006). Pembangunan Ekonomi Edisi ke-9. (H. Munandar \& A. L. Puji, Eds.). Jakarta: Erlangga.

Wesnawa, I. G. A., \& Christiawan, P. I. (2014). Geografi Bencana. Jakarta: Graha Ilmu. 